Efectos del cambio climático en la distribución

de una especie críticamente amenazada

\title{
Effect of climate change on the distribution of a critically threatened species
}

\author{
Eugenia C. Sántiz ${ }^{1}$, Consuelo Lorenzo ${ }^{1 *}$, Arturo Carrillo-Reyes ${ }^{2}$, Darío A. Navarrete ${ }^{3}$ and Gerald Islebe ${ }^{4}$
}

\begin{abstract}
${ }^{1}$ Departamento de Conservación de la Biodiversidad, El Colegio de la Frontera Sur, Carretera Panamericana y Periférico Sur s/n. C. P. 29290. San Cristóbal de Las Casas, Chiapas, México. E-mail: esantiz@ecosur.edu.mx (ECS), clorenzo@ecosur.mx (CL).

2 Oikos: Conservación y Desarrollo Sustentable, A.C., Calle Bugambilias 5, Col. Bismark, C.P. 29267, San Cristóbal de las Casas, Chiapas, México. E-mail: arturocarrilloreyes@gmail.com (ACR).

${ }^{3}$ Laboratorio de Información Geográfica, El Colegio de la Frontera Sur, Carretera Panamericana y Periférico Sur s/n. C. P. 29290. San Cristóbal de Las Casas, Chiapas, México. E-mail: dnavarre@ecosur.mx (DAN).

${ }^{4}$ Departamento de Conservación de la Biodiversidad, El Colegio de la Frontera Sur, Av. del Centenario Km. 5.5. C.P. 77900. Chetumal, Quintana Roo, México. E-mail: gislebe@ecosur.mx (Gl).

${ }^{*}$ Corresponding author
\end{abstract}

Climate change (CC) is modifying the habitat and distribution of wild fauna, causing distribution area reduction and/or altitudinal or latitudinal movements of species in response to increased temperatures and changes in precipitation. This increases the risk of species extinction, particularly for those with small population sizes, habitat specialists, microendemics and/or those with already restricted distributions. We examine how the effects of CC could influence the distribution and availability of habitat for the critically threatened and endemic species: the Tehuantepec jackrabbit (Lepus flavigularis) as well as the species of grasses on which it feeds. Our models were constructed using Maxent. Occurrence data of jackrabbits and grasses from the years 1959 to 2014 were analyzed, along with climatic and slope variables for three time periods, present (2014) and future (2050 and 2070). The climatic variables were taken from WorldClim (resolution: 30"), utilizing the HadGEM2-ES model with scenarios 4.5 and 8.5. Potential distribution models estimate an area of 9,274 ha of habitat suitable for the jackrabbit in 2014, with a $19.3 \%$ increment in this area to 11,071 ha by 2070 with scenario 4.5 and $9 \%$ increment with an area of 10,111 ha by 2070 with scenario 8.5 . According to a Jackknife analysis, Precipitation of Wettest Month (BIO13), and Precipitation of Warmest Quarter (BIO18) are the variables that contribute most to the construction of the potential distribution models of L. flavigularis, from 2014 to 2070. Future scenarios (4.5 and 8.5) estimate temperature increase and precipitation reduction in places where jackrabbits and grasses currently inhabit. Also, these scenarios estimate an increase in areas with suitable climatic conditions in the future. However, anthropogenic factors (not considered in this study) have influenced the distribution and retention of the populations of $L$. flavigularis in the study area, so the outlook of the species is not encouraging. It is clear that CC will have an effect on the distribution of this critically threatened and endemic species, through modification of the area and distribution of its available habitat.

El cambio climático (CC) y sus consecuencias sobre las variables climáticas (temperatura, precipitación) pueden poner en mayor riesgo la supervivencia de especies en categoría de amenaza, distribución restringida y/o endémica. Determinamos cómo los efectos del CC influyen sobre la distribución y disponibilidad de hábitat de una especie críticamente amenazada y endémica, la liebre de Tehuantepec, Lepus flavigularis y de las especies de pastos de las que se alimenta. Los modelos fueron elaborados con el programa Maxent, se analizaron datos de ocurrencia de la liebre y de los pastos del año 1959 al 2014, con variables climáticas y pendiente en tres periodos de tiempo, presente (2014) y futuro (2050 y 2070). Las variables climáticas fueron tomadas de WorldClim (resolución: 30"), del modelo HadGEM2-ES para los escenarios 4.5 y 8.5. Los modelos de distribución potencial estiman una superficie de 9,274 ha de hábitat adecuado para la liebre en 2014, con un incremento del 19.3\% de esta superficie a 11,071 ha para el 2070 con el escenario 4.5 y un incremento del $9 \%$ de su superficie a 10,111 ha al 2070 con el escenario 8.5. La precipitación del mes más húmedo (BIO13), y precipitación del trimestre más cálido (BIO18) fueron las variables con mayor contribución a la construcción de los modelos de distribución potencial de L. flavigularis según el análisis de Jacknife, para el periodo de 2014 al 2070. Los escenarios futuros (4.5 y 8.5) estiman incrementos de temperatura y una reducción de la precipitación en los sitios donde se registran actualmente las liebres y los pastos y se estima un incremento de los sitios con condiciones climáticas adecuadas para la liebre en el futuro. Sin embargo, factores antropogénicos (no considerados en este estudio) han determinado la distribución y permanencia de las poblaciones de L. flavigularis en el área de estudio, por lo que el panorama de la especie no es alentador. Se evidencia que el CC tiene un efecto en la distribución de una especie críticamente amenazada y endémica, al modificar la superficie y distribución de su hábitat disponible.

Key words: climate change, distribution range, endemic, Lepus flavigularis, Oaxaca, Tehuantepec jackrabbit.

๑ 2016 Asociación Mexicana de Mastozoología, www.mastozoologiamexicana.org 


\section{Introduction}

Climate change (CC) is modifying the habitat and distribution of wild fauna, causing distribution area reduction and/or altitudinal or latitudinal movements of species (Thuiller et al. 2004; Leach et al. 2014) in response to increased temperatures (Camacho et al. 2010) and changes in precipitation, thereby increasing their risk of extinction. Species with small populations, habitat specialists, or those that are included in a category of risk could be the most vulnerable to a reduced distribution range and to degradation or loss of their habitat in the future (Thuiller et al. 2004; Camacho et al. 2010). Models of potential distribution and ecological niche (the set of ecological conditions required by a species to maintain populations within a defined region) are reliable tools for determining the factors that control the distribution of species (Hutchinson 1957; Peterson et al. 2002; Peterson 2003; Siqueira and Peterson 2003; Peterson et al. 2004; Thuiller et al. 2004; Soberón and Peterson 2005; Jackson et al. 2009; Armenteras and Mulligan 2010) as well as their environmental requirements and therefore the availability and suitability of habitat (Peterson 2003; Siqueira and Peterson 2003; Peterson et al. 2004; Parra et al. 2005; Sánchez-Cordero et al. 2005; Levinsky et al. 2007; Elith and Leathwick 2009; Jackson et al. 2009).

Detailed observations (occurrence data) of the species and maps of climatic and slope variables, are required as explanatory variables of species distribution (McCarty 2001; Peterson et al. 2004; Sánchez-Cordero et al. 2005; Soberón and Peterson 2005). Previous studies have used climatic variables to project future distributions of species (Hampe 2004; Thuiller et al. 2004; Bomhard et al. 2005; Heikkinen et al. 2006; Triviño et al. 2011).

Knowledge of the current potential distribution and future of species in danger of extinction in Mexico would allow conservation efforts to be focused on sites that present the ecological features required by these species. Therefore, it is important to determine the implications of climate change for these species, using the Tehuantepec jackrabbit Lepus flavigularis, as a case study. This species is endangered according to NOM-ECOL-059 (SEMARNAT 2010), and Red List (IUCN 2012), is endemic to the south of the Isthmus of Tehuantepec and has a very restricted distribution (Cervantes 1993; Lorenzo et al. 2000; Lorenzo et al. 2006; Carrillo-Reyes et al. 2010). This jackrabbit inhabits savannas and introduced grasslands (Farías 2004; Lorenzo et al. 2006; Carrillo-Reyes et al. 2010; Sántiz et al. 2012), and feeds mainly on grasses (66.7 \%; Lorenzo et al. 2011). The major current threats to this species are loss and fragmentation of its habitat and poaching (Lorenzo et al. 2006; Cervantes et al. 2008; Carrillo-Reyes et al. 2010; Rioja et al. 2011).

The effect of climate change on 87 species of lagomorphs (rabbits, jackrabbits and pikas) is predicted to be a reduction and/or modification in their distribution, with latitudinal movements towards the poles, especially in the species of rabbit and jackrabbit, while altitudinal changes are predicted for the pikas. Specifically, a $45 \%$ decrease in the distribution of L. flavigularis is predicted, along with latitudinal changes of around $1{ }^{\circ}$ towards the poles and an average altitudinal increase of approximately $450 \mathrm{~m}$ (Leach et al. 2014). That study subjectively evaluates the effect of climate change on distribution (good, medium or poor) from just eight historical and modern records. For these reasons, it is considered that the model offers a poor representation of past and future distributions of L. flavigularis, and is thus unreliable (Leach et al. 2014). In the case of grasses, the global warming or the increase in $\mathrm{CO}_{2}$, may favor the distribution of some species depending on their photosynthetic pathways (Collatz et al. 1998; Duckworth et al. 2000; Hopkins and del Prado 2007; Osborne 2008; Lattanzi 2010; Chamaillé-Jammes and Bond 2010).

The present study aims to: a) model the potential distribution of L. flavigularis and grasses that support it in the south of the Isthmus of Tehuantepec, Oaxaca, México, b) understand the implications of climatic variables (temperature and precipitation), on the distribution of suitable areas for the jackrabbit in the present (2014) and future (2050 and 2070), under climate change 
scenarios, and c) identify the specific climatic variables that determine the distribution of these species (jackrabbit and relevant grasses).

\section{Material and Methods}

Study area. The study area is located in the state of Oaxaca, México, in the south of the Isthmus of Tehuantepec $\left(16.61^{\circ} \mathrm{N},-95.36^{\circ} \mathrm{W}\right.$ and $16.11^{\circ} \mathrm{N},-94.24^{\circ} \mathrm{W} ; 0$ a $100 \mathrm{~m}$; Ortiz et al. 2004; Figure 1). The climate is warm sub-humid with the occurrence of a dry period in mid-summer. Annual mean temperatures are above $26{ }^{\circ} \mathrm{C}$ and total annual precipitation is $800 \mathrm{~mm}$ (García 1988). The vegetation is composed of scrub and mangrove with submerged vegetation in the coastal lagoons (Ortiz et al. 2004). There are also extensive areas of savanna with isolated nanche (Byrsonima crassifolia (L.) Kunth (1822) and morro (Crescentia alata Kunth (1819) trees (Rzedowski 2006; Sántiz et al. 2012). In the driest parts of the Isthmus there are important areas of tropical low deciduous and low spiny deciduous forests that are remnants of tropical medium sub-deciduous forest (Torres-Colín 2004), and introduced grasses occur at sites from which the original vegetation has been eliminated. The Gramineae that dominate the herbaceous stratum of the savannas and introduced grasslands are of the genera Aristida, Bouteloua, Cathestecum, Cenchrus, Digitaria, Eragrostis, Panicum, Paspalum, and Schizachyrium (Rzedowski 2006; INEGI 2012; Sántiz et al. 2012).

Potential distribution models. The models were constructed using the Maxent v. 3.3 software (Elith et al. 2010) that generates probability maps of suitable or unsuitable habitat for the species of interest (Elith and Leathwick 2009). Maxent only requires presence data and provides species response curves for different environmental variables, estimating the importance of each variable in terms of the distribution of the species (Phillips et al. 2006). Records (205) of L. flavigularis were compiled from the GBIF (Global Biodiversity Information Facility; www.gbif.org) database of 1960 to 2000, and field records from 2001 to 2014 were also used. Additionally, 124 records of 8 species of grasses that feed the jackrabbit were collected from 1959 to 2012, and were taken

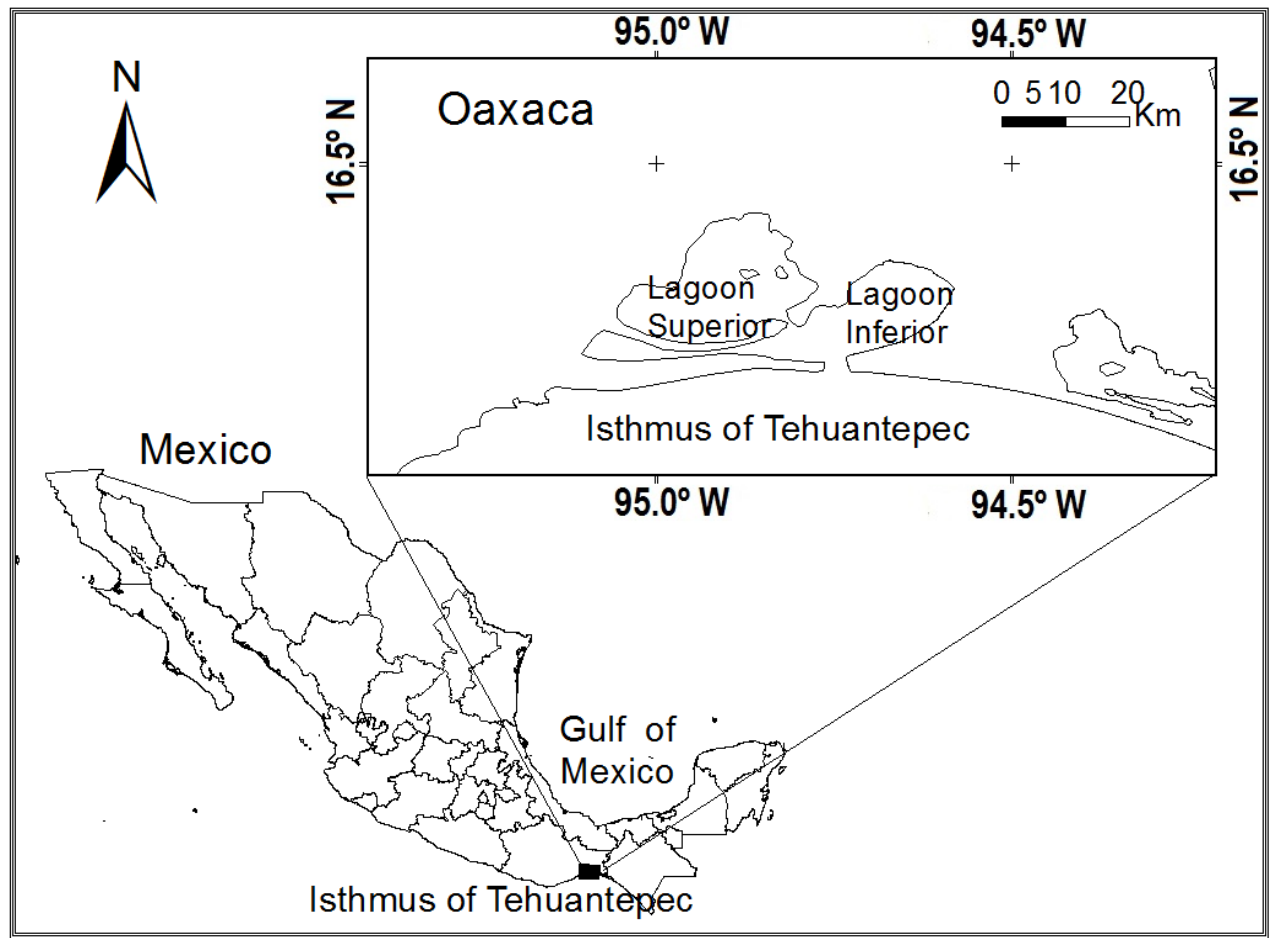

Figure 1. Location of the study area in the south of the Isthmus of Tehuantepec, Oaxaca, México. 
from the databases of the CONABIO (Herrera 1997; Aragón 2001; Panero 2003; Villaseñor 2008), data provided by Rioja et al. (in review) and field data from 2011 to 2014. The database of records was cleansed of repeated records, those from outside the study area, and those located in water bodies by errors.

Explanatory variables. The climatic variables for 2000, 2050, and 2070 conditions were taken from WorldClim (resolution: 30"; Hijmans et al. 2005). Initial selection was carried out with a test of correlation between the climatic variables, choosing those with correlation values lower than 0.7 (Gormley et al. 2011). A first analysis in Maxent was then conducted with the variables chosen according to the correlation test and variables with a contribution of less than $0.5 \%$ were eliminated (Warren et al. 2014) in order to produce the final models. The variables considered in the final analysis for jackrabbits were: slope (slop), annual mean temperature (BIO1), mean diurnal range (BIO2), temperature Seasonality (BIO4), mean temperature of coldest month (BIO6), temperature annual range (BIO7), mean temperature of driest quarter (BIO9), annual precipitation (BIO12), precipitation of wettest month (BIO13), precipitation seasonality (BIO15), precipitation of wettest quarter (BIO16), and precipitation of warmest quarter (BIO18). The variables used for grasses were: slope (slop), mean diurnal range (BIO2), isothermality (BIO3), temperature seasonality $(\mathrm{BIO} 4)$, temperature annual range (BIO7), mean temperature of warmest quarter (BIO10), precipitation of wettest month (BIO13), precipitation of driest month (BIO14), precipitation seasonality (BIO15), precipitation of wettest quarter (BIO16), precipitation of warmest quarter (BIO18), precipitation of coldest quarter (BIO19).

In order to highlight the effect of climate on the distribution of the jackrabbit and to forecast trends for the years 2050 and 2070, the bioclimatic layers of the HadGEM2-ES model with scenarios 4.5 and 8.5 were chosen. These represent the less severe and most extreme conditions with high concentrations of $\mathrm{CO}_{2}$, respectively (Hijmans et al. 2005; Riahi et al. 2007). All of the layers of the explanatory variables were homogenized to the raster format (pixels of $30 \mathrm{~m}$ ), datum WGS84 and to geographic coordinates, and subsequently to the ASCII format. The models of 2014, 2050 and 2070 were constructed with 123 records for training and 82 records for test with a total of 205 records, and for grasses were developed with 124 total records, of which 93 were used in the calibration and 31 for the validation of the models. A total of 20 replicates were run, with 1000 iterations, and a total of 5 distribution maps were selected based on highest AUC (area under

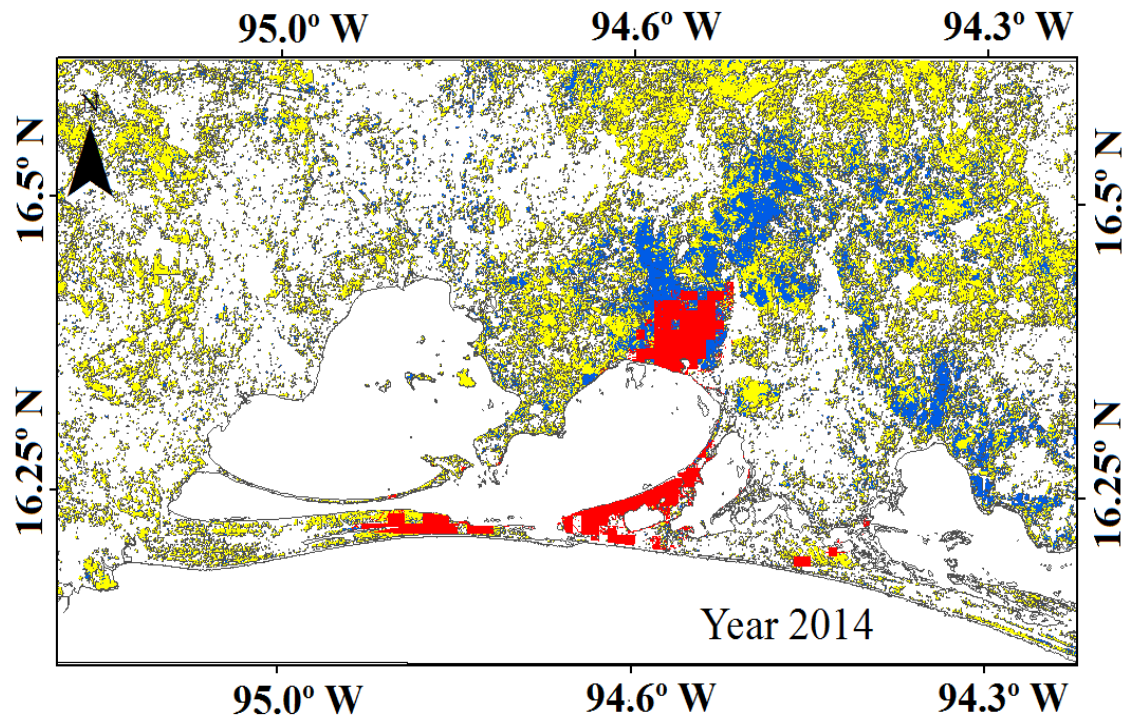

Figure 2. Based on the model for 2014, the potential distribution in the south of the Isthmus of Tehuantepec of: habitat suitable for the presence (in red) of Lepus flavigularis and forage grasses; the vegetation of savannas (dark blue); and grasslands dominated by introduced species (light yellow). 
the curve) values. The AUC of the Receiver Operating Characteristic (ROC) graphics was used. This statistic allows evaluation of correctly classified cases for all of the prediction thresholds (from 0 to 1). The value of the AUC is between 0.5 and 1 . A value of 0.5 equates to a random classification, while a value of 1 indicates a perfect fit, i.e., that all of the cases have been correctly classified (Fielding and Bell 1997).

The five chosen distribution maps were converted to maps of presence-absence, fixing the thresholds of probability of species presence (Jiménez-Valverde and Lobo 2007) in ArcGis 10.2 software (ESRI 2011). Fixed cumulative value 10 threshold was selected because the species of interest has a limited distribution. When predicted area is limited by this factor, the false positives are also reduced (predicted distribution sites, which lack suitable conditions for species distribution), and the true positives increase (predicted distribution sites, in which suitable conditions for species distribution are present). This area could be of utility in the identification of new potentially suitable zones for the establishment of the species, possible zones of reintroduction or vital zones for establishing protection measures, and reducing human pressure (Peterson et al. 2011). The final maps were obtained from multiplying the five best maps with map algebra in Spatial analyst tool of ArcGis 10.2 software (ESRI 2011).

In order to know the types of vegetation in climate suitable sites where the jackrabbits and grasses occur, a map of the vegetation and land use for 2015, was developed through a multispectral satellite image of Landsat 8 Oli, and with resolution of $30 \mathrm{~m}$ from 2015. Maximum likelihood algorithm was used in the GRASS module for QGIS (version 2.10), to carry out a supervised classification. Classification discriminated $80 \%$ of the errors obtained to carry out a classification at random. The kappa index resulted in an accuracy of $82 \%$.

\section{Results}

Environmental requirements of Lepus flavigularis. According to the records of the presence of the Tehuantepec jackrabbit in the study area, it is found in zones with little slope $\left(0-7.34^{\circ}\right)$, with mean annual temperatures of $27.15{ }^{\circ} \mathrm{C}$, and with total annual precipitation of 1,165 mm in 2014 (Table 1).

Distribution models of Lepus flavigularis and grasses. Over the total study period, distribution models estimate an increase in suitable area for the species in both scenarios (4.5 and 8.5). The climate suitable area for the presence of jackrabbits and its food resource according to the models, is 9,274 has (Figure 2), in the current scenario (2014). In the future, scenario 4.5 estimated a reduction of the available range to 7,510 ha's, by 2050 and an increase to 11,071 ha's in 2070 . However, scenario 8.5 estimates increases of the suitable range to 11,649 ha's in 2050 and 10,111 ha's in 2070 (Figure 3).

Contribution of the variables. According to a Jacknife analysis (which determines the variable that most contributes to the potential niche), of the 12 explanatory variables included in the potential distribution models of suitable habitat, 10 variables explain more than $85 \%$ of the ecological niche of L. flavigularis, in the models. At the current scenario, variables $\mathrm{BIO} 18$ and $\mathrm{BIO} 13$ contributed the most to the model. At the 4.5 scenario, most important variables were $\mathrm{BIO} 13$ and $\mathrm{BIO} 7$ in 2050, and $\mathrm{BIO} 13$ and $\mathrm{BIO6}$ for 2070. At the 8.5 scenario, variables which contributed the most were $\mathrm{BIO} 13$ and $\mathrm{BIO} 12$ in 2050, and $\mathrm{BIO} 18$ and $\mathrm{BIO} 7$ for 2070 (Table 2). For grasses, the variables 
Table 1. Mean values of the conditions of temperature $\left({ }^{\circ} \mathrm{C}\right)$ and precipitation $(\mathrm{mm})$ for 2014 in the site where Lepus flavigularis has been recorded, and the possible conditions in 2050 and 2070, according to the HadGEM2-ES model with scenarios 4.5 and 8.5 , in the Isthmus of Tehuantepec, in Oaxaca, México.

\begin{tabular}{|c|c|c|c|c|c|}
\hline \multirow[b]{2}{*}{ VARIABLE } & \multirow[b]{2}{*}{2014} & \multicolumn{2}{|c|}{ Scenario 4.5} & \multicolumn{2}{|c|}{ Scenario 8.5} \\
\hline & & 2050 & 2070 & 2050 & 2070 \\
\hline Annual mean temperature (BIO1) & 27.1 & 29.4 & 30.0 & 30.1 & 31.5 \\
\hline Mean Diurnal Range (BIO2) & 107.0 & 108.0 & 109.0 & 109.0 & 108.5 \\
\hline Temperature Seasonality (BIO4) & 12.9 & 14.6 & 14.8 & 15.1 & 16.8 \\
\hline Minimum temperature in the coldest month (BIO6) & 19.2 & 21.2 & 21.7 & 21.9 & 23.1 \\
\hline Temperature Annual Range (BIO7) & 15.7 & 15.8 & 16.0 & 16.0 & 16.1 \\
\hline Mean temperature of the driest trimester (BIO9) & 25.3 & 27.5 & 28.0 & 28.1 & 29.5 \\
\hline Annual precipitation (BIO12) & $1,149.5$ & $1,023.5$ & $1,056.5$ & $1,057.0$ & 980.5 \\
\hline Precipitation of the most humid month (BIO13) & 299.5 & 264.0 & 270.5 & 260.5 & 240.0 \\
\hline Precipitation Seasonality (BIO15) & 111.0 & 107.5 & 105.5 & 105.0 & 104.0 \\
\hline Precipitation of the wettest trimester (BIO16) & 703.5 & 630.5 & 596.0 & 581.0 & 542.5 \\
\hline Precipitation of the warmest trimester (BIO18) & 345.5 & 395.5 & 369.0 & 388.0 & 493.5 \\
\hline
\end{tabular}

with the greatest contribution to the construction of models was $\mathrm{BIO} 2$ for the 3 years (2014, 2050 and 2070), and the two scenarios analyzed, followed by BIO16 in 2014, and 2070 with the scenario 4.5, BIO13 in 2050 with the scenario 4.5, BIO 19 in 2050 with the scenario 8.5 and the isothermality for 2070 with the scenario 8.5 (Table 2).

\section{Discussion}

The potential distribution of suitable habitat (sites climatically suitables) for the jackrabbit (and grasses) is restricted to types of vegetation as savannas and introduced grasslands that present little slope. This coincides with the information available for this species, which places it in zones dominated by open grasslands (Cervantes 1993; Vargas 2000; Lorenzo et al. 2006), or savannas that are associations of natural grasslands with isolated morro trees (Crescentia alata), or isolated patches of nanche trees (Byrsonima crassifolia) typical of flat or slightly inclined areas (Farías 2004; Sántiz et al. 2012). Unfortunately, the vegetation inhabited by the jackrabbit is strongly threatened by agriculture (e.g., crops of sorghum and maize) and livestock production, activities that have led to the degradation and reduction of the natural
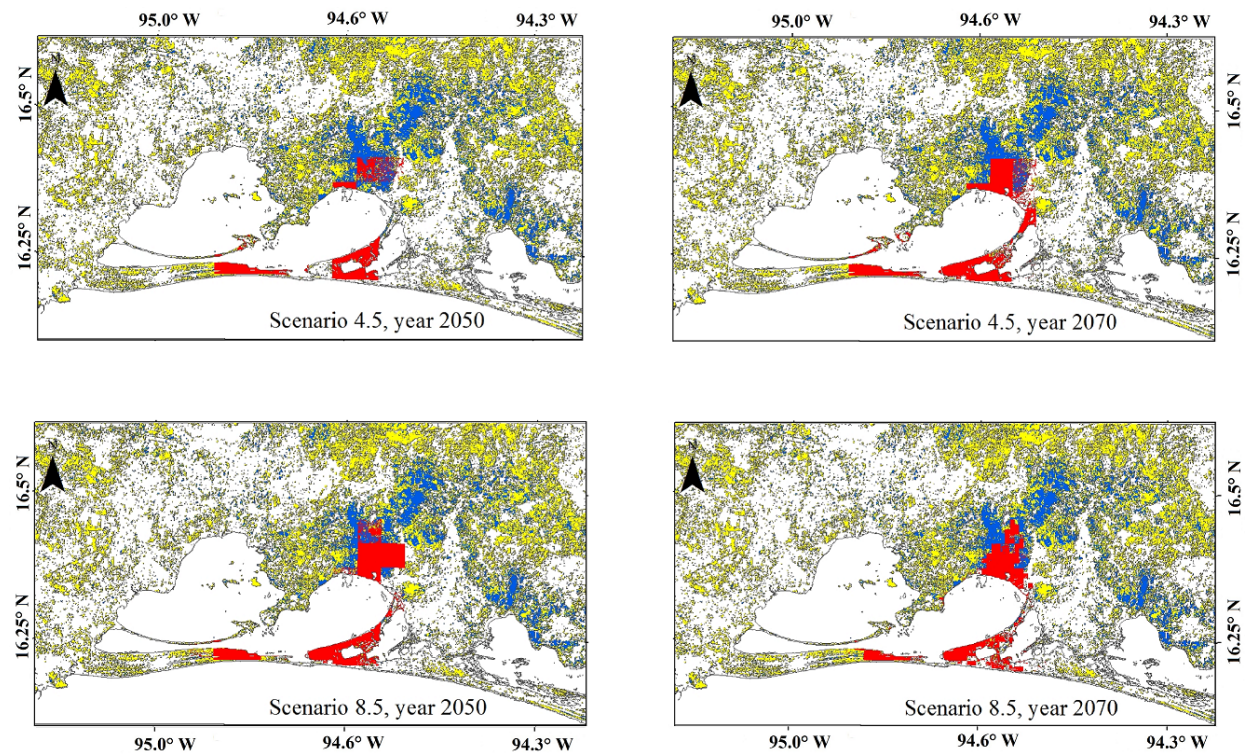

Figure 3. Using the models for 2050 and 2070 , scenarios 4.5 and 8.5 , potential distributions in the south of the Isthmus of Tehuantepec of: suitable habitat for the presence (in red) of Lepus flavigularis and forage grasses; the vegetation of savannas (dark blue); and grasslands dominated by introduced species (light yellow). 
vegetation, and that cause the disappearance of the original pristine grasses and modify the plant species composition, as reported in other regions of the country (Anderson 2006; CONABIO 2006; Rzedowski 2006; Estrada-Castillón et al. 2010).

Climatic variables such as Precipitation of Wettest Month (BIO13), and Precipitation of Warmest Quarter (BIO18), Min Temperature of Coldest Month (BIO6), Temperature Annual Range (BIO7) and annual precipitation (BIO12), are also factors of great importance in the delimitation of the niche of this jackrabbit. In previous studies, temperature and precipitation have been closely related to the reproduction and density of lagomorphs (rabbits and jackrabbits; Pévet 1987; Portales-Betancourt et al. 2012). The increased availability of food signals the beginning of the reproductive season (Pévet 1987). In Texas, USA, the peak in reproduction of the lagomorphs (from January to April) coincided with an increase in this vegetation-type that is determined mainly by the temperature and quantity of precipitation (Dunn et al. 1982). Lepus californicus in New Mexico, USA, and the Mapimi Biosphere Reserve in Durango, Mexico, presented differences in densities between years, due to variations in levels of precipitation (Daniel et al. 1993; Portales-Betancourt et al. 2012). In L. flavigularis, there is a strong positive relationship between seasonality and reproduction, defined by photoperiod (day length) and ambient temperature and rainfall, since this influences testicular development (Rioja et al. 2011) and, as with other jackrabbits such as L. californicus, this influences the phases of estrus and female receptivity (Portales-Betancour et al. 2004; 2012).

This study estimated an increase in the distribution of the jackrabbit of $19.3 \%$ with the scenario 4.5 and 9\% with scenario 8.5, in a period of 56 years (2014 - 2070), with no changes to its latitudinal and altitudinal distribution predicted. These results differ from that estimated previously, where a $45 \%$ decrease in its distribution was predicted with latitudinal changes of around $1^{\circ}$ towards the poles and a mean altitudinal increase of around 450 m over a longer time period (150 years; 1930 to 2080; Leach et al. 2014).

The HadGem model with the 4.5 and 8.5 scenario in 2050 and 2070 estimates increased temperature and decreased precipitation in the study area and, according to the predictions of the models, the future availability of sites with weather conditions favorable for jackrabbits and their food (grasses) may increase. However, even if there are appropriate climatic conditions for the establishment of jackrabbits and their food in the future, the outlook for L. flavigularis is not favorable. Changes in vegetal cover and land use, agriculture, livestock, and the presence of human settlements, have led to the decrease of the area of distribution and abundance of $L$. flavigularis (Lorenzo et

Table 2. Estimated sizes of suitable grassland habitat, and variables of greatest contribution to the ecological niche models of Lepus flavigularis for each of the years 2014, 2050 and 2070.

\begin{tabular}{|c|c|c|c|c|}
\hline & Scenario & Year & Area (ha) & Variables with greatest contribution \\
\hline \multirow[t]{5}{*}{ Lepus flavigularis } & & 2014 & 13,672 & $\mathrm{BIO} 18, \mathrm{BIO} 13, \mathrm{BIO} 2$ \\
\hline & 4.5 & 2050 & 16,842 & $\mathrm{BIO} 13, \mathrm{BIO} 7, \mathrm{BIO} 2$ \\
\hline & & 2070 & 15,226 & $\mathrm{BIO} 13, \mathrm{BIO6}, \mathrm{BIO} 15$ \\
\hline & 8.5 & 2050 & 14,275 & $\mathrm{BIO} 13, \mathrm{BIO} 12, \mathrm{BIO} 2$ \\
\hline & & 2070 & 14,850 & $\mathrm{BIO} 18, \mathrm{BIO} 7, \mathrm{BIO} 16$ \\
\hline \multirow[t]{5}{*}{ Grasses } & & 2014 & 9,991 & $\mathrm{BIO} 2, \mathrm{BIO} 16, \mathrm{BIO} 4$ \\
\hline & 4.5 & 2050 & 22,394 & $\mathrm{BIO} 2, \mathrm{BIO} 13, \mathrm{BIO} 19$ \\
\hline & & 2070 & 29,036 & $\mathrm{BIO} 2, \mathrm{BIO} 16, \mathrm{BIO} 19$ \\
\hline & 8.5 & 2050 & 26,876 & $\mathrm{BIO} 2, \mathrm{BIO} 16, \mathrm{BIO} 19$ \\
\hline & & 2070 & 27,614 & $\mathrm{BIO} 2, \mathrm{BIO} 3, \mathrm{BIO} 16$ \\
\hline
\end{tabular}


al. 2000, 2006, 2008, 2014; Vargas 2000; Farías 2004; Sántiz 2002, 2005), and have led to the fragmentation of its habitat, causing the isolation of their populations and low genetic variability, which has aggravated their situation (Flux and Angermann 1990; Cervantes 1993; Vargas 2000; Rico et al. 2008).

Moreover, changes in cover and land uses, have caused loss and modification of the vegetal cover that favors both the jackrabbit (savannas) and an increase in human settlements. In the study area, an increase of $2.1 \%$ per year has been reported in the area of human settlements since 1986. Moreover, savannas have decreased their distribution at a rate of $1.2 \%$ per year in the same period, with a loss of $6,850.6$ ha's over a period of 26 years (1986-2012; unpublished data). Overhunting is also another anthropogenic factor that has caused a decrease in the density of the populations of this species, contributing to the current situation (Farías 2004; Lorenzo et al. 2008). The impacts of these threats in the future to populations of jackrabbits and habitat could be greater and felt over a shorter time span than those of climate change.

Implications for the conservation of Lepus flavigularis. Conservation of L. flavigularis will present new challenges; success will depend on our capacity for working in unison with local inhabitants and decision-makers (Lidicker 2015). While climate change will modify the area considered as suitable habitat for L. flavigularis, other factors already exist that threaten and modify the distribution of its populations and habitat. Land use changes for activities such as livestock production and agriculture, as well as the expansion of human settlements, are already reducing the natural vegetation (savannas) in the study area (Lorenzo et al. 2006; Rzedowski 2006; INEGI 2012). For this reason, promotion of the establishment of a communal ecological reserve, administrated by the local authorities and with the technical assistance of academic personnel is one option by which to avoid the continued reduction of the habitat of the jackrabbit and to contribute to the protection of the species. Local protected areas have proven to have strengths related to dedication of the required land and its heritage of natural resources by the local communities for conservation. Such actions can be expected to also improve the quality of life for local inhabitants, since these people are currently in a socioeconomically poor situation with a lack of opportunities for work (Vargas 2001). Further research is necessary to improve our understanding of the composition of and interactions among the species of grasses comprising the plant associations in which the jackrabbit lives. It will also be critically important to establish appropriate management strategies for the grassland and savanna communities in order to avoid further degradation of the remaining populations of the Tehuantepec jackrabbit.

\section{Acknowledgements}

We appreciate the help of J. Bolaños, X. Sántiz, M. Ruiz in the fieldwork. We thank M. Gómez and M. Martínez for their support in the determination of grasses. Thanks also to the families Antonio Gutiérrez and Gutiérrez Vázquez for their support in the field. Finally, we thank two anonymous reviewers for their help in the review of this manuscript.

\section{Literature cited}

Anderson, R. C. 2006. Evolution and origin of the Central Grassland of North America: climate, fire, and mammalian grazers. Journal Torrey Botanical Society 133:626- 
647.

Aragón, L. 2001. Etapa final de la captura y catalogación del Herbario del Instituto de Ecología, A. C., Centro Regional del Bajío. Instituto de Ecología, A. C. Bases de datos SNIB-CONABIO Proyecto no. Q017.

Armenteras, D., And M. Mulligan. 2010. Modelling the potential distribution of tree species on a national scale in Colombia: application to Palicourea angustifolia Kunth and Palicourea guianensis. Aubl. Caldasia 32:355-380.

Bomhard, B., D. M. Richardson, J. S. Donaldson, G. O. Hughes, G. F. Midgley, D. C. Raimondo, A. G. Rebelo, M. Rouget, And W. Thuiller. 2005. Potential impacts of future land use and climate change on the Red List status of the Proteaceae in the Cape Floristic Region, South Africa. Global Change Biology 11:1452-1468.

Camacho, A., E. Minteer, B. A. Doremus, and J. S. Mclachllan. 2010. Perspectives: Reassessing Conservation Goals in a Changing Climate. Issues in science and technology. University of Texas. Dallas, EE. UU.

Carrillo-Reyes, A., C. Lorenzo, E. J. Naranjo, M. Pando, and T. Rioja. 2010. Home range dynamics of the Tehuantepec Jackrabbit in Oaxaca, Mexico. Revista Mexicana de Biodiversidad 81:143-151.

Cervantes, F. A. 1993. Lepus flavigularis. Mammalian Species 423:1-3.

Cervantes, F. A., C. Lorenzo, V. Farías, and J. Vargas. 2008. Lepus flavigularis IUCN Red List of Threatened Species. Version 2011.2.

Chamaillé-Jammes, S., AND W. J. Bond. 2010. Will global change improve grazing quality of grasslands? A call for a deeper understanding of the effects of shifts from $C_{4}$ to $C_{3}$ grasses for large herbivores. Oikos 119:1857-1861.

conabio (Comisión Nacional para el Conocimiento y Uso de la Biodiversidad). 2006. Capital natural y bienestar social, Comisión Nacional para el Conocimiento y Uso de la Biodiversidad. Ciudad de México, México.

Collatz, G. J., J. A. BerRY, AND J. S. Clark. 1998. Effects of climate and atmospheric partial pressure on the global distribution of $C_{4}$ grasses: present, past and future. Oecologia 114:441-454.

Daniel, A., J. Holechek, R. Valdez, A. Tembo, L. Saimana, M. Fusco, and M. Cardenas. 1993. Jackrabbit densities on faire and good condition Chihuahuan desert range. Journal Range Management 46:524-528.

Duckworth, J. C., R. G. H. Bunce, And A. J. C. Malloch. 2000. Modelling the potential effects of climate change on calcareous grasslands in Atlantic Europe. Journal of Biogeography 27:347-358.

Dunn, J. P., J. A. Chapman, And R. E. Marsh. 1982. Jackrabbits (Lepus californicus and Allies). Pp. 146-163 in Wild Mammals of North America (Chapman, J. A., and G. A. Feldhamer, eds.). The Johns Hopkins University Press. Baltimore, EE. UU.

Elith, J., and J. R. Leathwick. 2009. Species distribution models: Ecological explanation and prediction across space and time. Annual Review of Ecology, Evolution and Systematics 40:677-97.

Elith, J., S. J. Phillips, T. Hastie, M. Dudík, Y. E. Chee, and C. J. Yates. 2010. A statistical explanation of Maxent for ecologists. Diversity and Distributions 17:43-57.

ESRI (Environmental Systems Research Institute). 2011. ArcGIS Desktop: Release 10, Environmental Systems Research Institute. Redlands, EE.UU.

Estrada-Castillón, E., L. Scott-Morales, J. A. Villarreal-Quintanilla, E. Jurado-Ybarra, M. Cotera-Correa, C. Cantú-Ayala, and J. García-Pérez. 2010. Clasificación de los pastizales halófilos del noreste de México asociados con perrito de las praderas (Cynomys mexicanus): diversidad y endemismo de especie. Revista 
Mexicana de Biodiversidad 81:401-416.

Farias, V. 2004. Spatio temporal ecology and habitat selection of the critically endangered tropical jackrabbit (Lepus flavigularis) in Oaxaca, México. Tesis de doctorado. University of Massachusetts. Amherst, EE. UU.

Fielding, H. A., AND J. F. Bell. 1997. A review of methods for the assessment of predictions errors in conservation presence/absence models. Environmental Conservation 24:38-49.

Flux, J. E. C., And R. Angermann. 1990. The hares and jackrabbits. Pp. 61-94 in Rabbits, hares and pika (Chapman, J.A., and J.E.C. Flux, eds). Status survey and Conservation Action Plan. International Union for the Conservation of Nature and Natural Resources. Gland, Switzerland.

García, E. 1988. Modificaciones al sistema de clasificación climática de Köppen (para adaptarlo a las condiciones de la República Mexicana). Instituto de Geografía. Universidad Nacional Autónoma de México. Ciudad de México, México.

Gormley, A. M., D. M. Forsyth, P. Griffioen, M. Lindeman, D. S. L. Ramsey, M. P. Scroggie, and L. WoodforD. 2011. Using presence-only and presence-absence data to estimate the current and potential distributions of established invasive species. Journal of Applied Ecology 48:25-34.

Hampe, A. 2004. Bioclimate envelope models: what they detect and what they hide. Global Ecology and Biogeography 13:469-76.

Heikkinen, R. K., M. Luoto, M. B. Araújo, R. Virkkala, W. Thuiller, and M. T. Sykes. 2006. Methods and uncertainties in bioclimatic envelope modelling under climate change. Progress in Physical Geography 30:751-777.

Herrera, Y. 1997. Estudio biosistemático del género Bouteloua (Poaceae) en México Centro Interdisciplinario de Investigación para el Desarrollo Integral Regional-Durango Instituto Politécnico Nacional. Bases de datos SNIB-CONABIO Proyecto no. B 61.

Hijmans, R. J., S. E. Cameron, J. L. Parra, P. G. Jones, and A. Jarvis. 2005. Very high resolution interpolated climate surfaces for global land areas. International Journal of Climatology 25:1965-1978.

Hopkins, A., And A. Del Prado. 2007. Implications of climate change for grassland in Europe: impacts, adaptations and mitigation options: a review. Grass and Forage Science 62:118-126.

Hutchinson, G. E. 1957. Concluding remarks. Cold Spring Harbor Symposia on Cuant. Biology 22:415-427.

INEGI (Instituto Nacional de Estadística y Geografía). 2012. Guía para la interpretación de cartografía. Uso del suelo y vegetación. Escala 1:250000. Serie IV. Ciudad de México, México.

IUCN (International Union for Conservation of Nature). 2012. Categorías y Criterios de la Lista Roja de la IUCN. Versión 3.1. Comisión de Supervivencia de Especies de la IUCN. IUCN, Gland, Suiza, Cambridge, Reino Unido.

Jackson, S. T., J. L. Betancourt, R. K. Booth, and S. T. Gray. 2009. Ecology and the rächet of events: climate variability, niche dimensions, and species distributions. Proceedings of the National Academy of Science 2:19685-1 9692.

Jiménez-Valverde, A., AND J. M. Lobo. 2007. Threshold criteria for conversion of probability of species presence to either-or presence-absence. Acta Oecologica 31:361-369.

Lattanzı, F. A. 2010. C3/C4 grasslands and climate change. Pp. 3-13 in Grassland in a changing world (Schnyder, H., J. Isselstein, F. Taube, K. Auerswald, J. Schellberg, M. Wachendorf, A. Herrmann, M. Gierus, N. Wrage, and A. Hopkins, eds). Universität 
Göttingen, European Grassland Federation. CIUDAD, Germany.

Leach, K., R. Kelly, A. Cameron, W. I. Montgomery, and N. Reid. 2014. Response to climate change is related to species traits in the Lagomorpha. http://biorxiv.org/ from

Levinsky, I., F. Skov, J. C. Svenning, and C. Rahbek. 2007. Potential impacts of climate change on the distributions and diversity patterns of European mammals. Biodiversity Conservation 16:3803-3816.

LIDICKER, W. Z. 2015. Mammalian conservation: scientific frontiers and socio-political pitfalls. Therya 6:1-10.

Lorenzo, C., O. Retana-Guiascon, F. A. Cervantes, J. Vargas, and G. L. Portales. 2000. Status survey of the critically endangered Lepus flavigularis. Final report to Chicago Zoological Society. El Colegio de la Frontera Sur. San Cristóbal de Las Casas, Chiapas, México.

Lorenzo, C., F. A. Cervantes, F. Barragán, and J. Vargas. 2006. New records of the endangered Tehuantepec jackrabbit (Lepus flavigularis) from Oaxaca, Mexico. The Southwestern Naturalist 51:116-119.

Lorenzo, C., T. M. Rioja, A. Carrillo, and F. A. Cervantes. 2008. Population fluctuations of Lepus flavigularis (Lagomorpha: Leporidae) at Tehuantepec Isthmus, Oaxaca, Mexico. Acta Zoológica Mexicana (n. s.) 24:207-220.

Lorenzo, C., A. Carrillo-Reyes, M. Gómez-Sánchez, A. Velázquez, and E. Espinoza. 2011. Diet of the endangered Tehuantepec jackrabbit, Lepus flavigularis. Therya 2:67-76.

Lorenzo, C., A. Carrillo-Reyes, T. M. Rioja-Paradela, M. de la Paz Cuevas, J. Bolaños Citalán, and S. T. Álvarez-Castañeda. 2014. Estado actual de conservación de liebres y conejos en categoría de riesgo en México. Technical Report. Project HK052. Comisión Nacional para el Conocimiento y Uso de la Biodiversidad.

McCARTY, J. P. 2001. Ecological Consequences of Recent Climate Change. Conservation Biology 15:320-331.

Ortiz, P., J. R. Hernández, and J. M. Figueroa. 2004. Reconocimiento Fisiográfico y geomorfológico. Pp. 43-54 in Biodiversidad de Oaxaca (García-Mendoza, A. J., M. J. Ordóñez, y M. Briones-Salas, eds.). Instituto de Biología, UNAM-Fondo Oaxaqueño para la Conservación de la Naturaleza - World Wildlife Fund. Ciudad de México, México.

Osborne, C. P. 2008. Atmosphere, ecology and evolution: what drove the Miocene expansion of C4 grasslands?. Journal of Ecology 96:35-45.

Panero, J. L. 2003. Catálogo electrónico de especímenes depositados en el Herbario de la, Universidad de Texas en Austin, Fase IV. Herbarium. The University of Texas. Bases de datos SNIB-CONABIO Proyecto no. AE013.

Parra, G., E. Martínez-Meyer, and G. Pérez. 2005. Forecasting climate change effects on Salamander distribution in the Highlands of central Mexico. Biotropica 37:202-208.

Peterson, A. T., M. A. Ortega-Huerta, J. Bartley, V. Sánchez-Cordero, J. Soberón, R. H. Buddemeier, AND D. R. B. Stockwell. 2002. Future projections for Mexican faunas under global climate change scenarios. Nature 416:626-629.

Peterson, A. T. 2003. Projected climate change effects on Rocky Mountain and Great Plains birds: generalities of biodiversity consequences. Global Change Biology 9:647-655.

Peterson, A. T., E. Martínez-Meyer, C. González-Salazar, and P. W. Hall. 2004. Modeled climate change effects on distributions of Canadian butterfly species. Canadian Journal of Zoology 82:851-858.

Peterson, A. T., J. Soberón, R. G. Pearson, R. P. Anderson, E. Martínez-Meyer, M. Nakamura, And M. B. Araúso. 2011. Ecological Niches and Geographic Distributions. Princeton University Press. Princeton, EE. UU.

Pévet, P. 1987. Environmental control of the annual reproductive cycle in mammals: role of 
the pineal gland. Comparative Physiology of Environmental Adaptations 3:82-100.

Phillips, S. J., R. P. Anderson, And R. E. Schapire. 2006. A maximum entropy modelling of species geographic distributions. Ecological Modelling 190:231-259.

Portales-Betancour, G., L. Hernández, F. A. Cervantes, and J. W. Laundre. 2004. Reproduction of Black-tailed jackrabbits (Lagomorpha: Lepus californicus) in relation to environmental factors in the Chihuahuan Desert, México. The Southwestern Naturalist 49:359-366.

Portales-Betancourt, G. L., L. Hernández, J. W. Laundré, and F. A. Cervantes. 2012. Reproducción y densidad de la liebre cola-negra (Lepus californicus) en relación a factores ambientales, en la Reserva de la Biosfera Mapimí, Desierto Chihuahuense. Therya 3:171-183.

Riahi, K., A. Gruebler, and N. Nakicenovic. 2007. Scenarios of long-term socio-economic and environmental development under climate stabilization. Technological Forecasting and Social Change 74:887-935.

Rico, Y., C. Lorenzo, F. X. González- Cózatl, and E. Espinoza. 2008. Phylogeography and population structure of the endangered Tehuantepec jackrabbit Lepus flavigularis: implications for conservation. Conservation Genetics 9:1467-1477.

Rioja, T., C. Lorenzo, E. Naranjo, L. Scott, and A. Carrillo-Reyes. 2011. Breeding and parental care in the endangered Tehuantepec jackrabbit (Lepus flavigularis). Western North American Naturalist 71:56-66.

Rioja, T., F. Hernández, G. Castañeda, A. Carrillo, C. Lorenzo, and M. Gómez. In review. Trophic interactions between an endangered mammal and cattle: Implications for management practices. Acta Oecologica.

Rzedowskı, J. 2006. Vegetación de México. Comisión Nacional para el Conocimiento y Uso de la Biodiversidad. Ciudad de México, México.

Sánchez-Cordero, V., C. Verónica, M. Munguía, and S. Sarkar. 2005. Place prioritization for biodiversity representation using species ecological niche modeling. Biodiversity Informatics 2:11-23.

Sántiz, E. 2002. Distribución y abundancia de la liebre endémica Lepus flavigularis y el conejo castellano Sylvilagus floridanus (Mammalia: Lagomorpha) en el Istmo de Tehuantepec, Oaxaca, México. Tesis de Licenciatura, Universidad de Ciencias y Artes de Chiapas. Tuxtla Gutierrez, México.

Sántiz, E. 2005. Selección de hábitat y densidad poblacional de la liebre del Istmo Lepus flavigularis (Wagner 1844) en Oaxaca, México. Tesis de Maestría, Instituto de Ecología, A. C. Xalapa, Veracruz, México.

Sántiz, E. C., A. González-Romero, C. Lorenzo, S. Gallina-Tessaro, and F. A. Cervantes. 2012. Uso y selección de asociaciones vegetales por la liebre de Tehuantepec (Lepus flavigularis) en Oaxaca, México. Therya 3:127-136.

Semarnat (Secretaría de Medio Ambiente y Recursos Naturales). 2010. Norma Oficial Mexicana NOM-059-ECOL-2010. Protección ambiental-especies nativas de México de flora y fauna silvestres-Categorías de riesgo y especificaciones para su inclusión, exclusión o cambio-Lista de especies en riesgo. Diario Oficial de la Federación. Ciudad de México, México.

Siqueira, M. F. D., And A. T. Peterson. 2003. Global climate change consequences for cerrado? tree species. Biota Neotropica 3:1-14.

Soberón, J., And A. T. Peterson. 2005. Interpretation of models of fundamental ecological niches and species' distributional areas. Biodiversity Informatics 2:1-10.

Thuiller, W., M. B. Araujo, and S. Lavorel. 2004. Do we need land-cover data to model 
species distributions in Europe?. Journal of Biogeography 31:353-361.

Torres-Colín, R. 2004. Tipos de vegetación. Pp. 105-117 in Biodiversidad de Oaxaca (GarcíaMendoza, A. J., M. J. Ordóñez, y M. Briones-Salas, eds.). Instituto de Biología, UNAMFondo Oaxaqueño para la Conservación de la Naturaleza - World Wildlife Fund. Ciudad de México, México.

Triviño, M., W. Thuiller, M. Cabeza, T. Hickler, and M. B. Araujo. 2011. The Contribution of Vegetation and Landscape Configuration for Predicting Environmental Change Impacts on Iberian Birds. PLoS ONE 6:1-10.

VARGAS, J. 2000. Distribución, abundancia y hábitat de la liebre endémica Lepus flavigularis (Mammalia: Lagomorpha). Tesis de Maestría, Facultad de Ciencias. Universidad Nacional Autónoma de México. Ciudad de México, México.

VARGAS, Z. 2001. Valoración de los vertebrados terrestres por huaves y zapotecas del Istmo de Tehuantepec, Oaxaca, México. Tesis de maestría, El Colegio de La Frontera Sur. San Cristóbal de Las Casas, Chiapas, México.

Villaseñor, J. L. 2008. La familia Asteraceae en México, fase V. Instituto de Biologia. Universidad Nacional Autónoma de México. Bases de datos SNIB-CONABIO Proyecto no. FE004.

Warren, D. L, A. N. Wright, S. N. Seifert, and H. B. Shaffer. 2014. Incorporating model complexity and spatial sampling bias into ecological niche models of climate change risks faced by 90 California vertebrate species of concern. Diversity and Distribution 20:334-343.

Submited: November 20, 2015

Reviewed: January 26, 2016

Accepted: January 26, 2016

Associated editor: Williams Lidicker 
160 THERYA Vol.7 (1): 147-159 